\title{
Medical Image of the Week: Fournier's Gangrene with a Twist
}
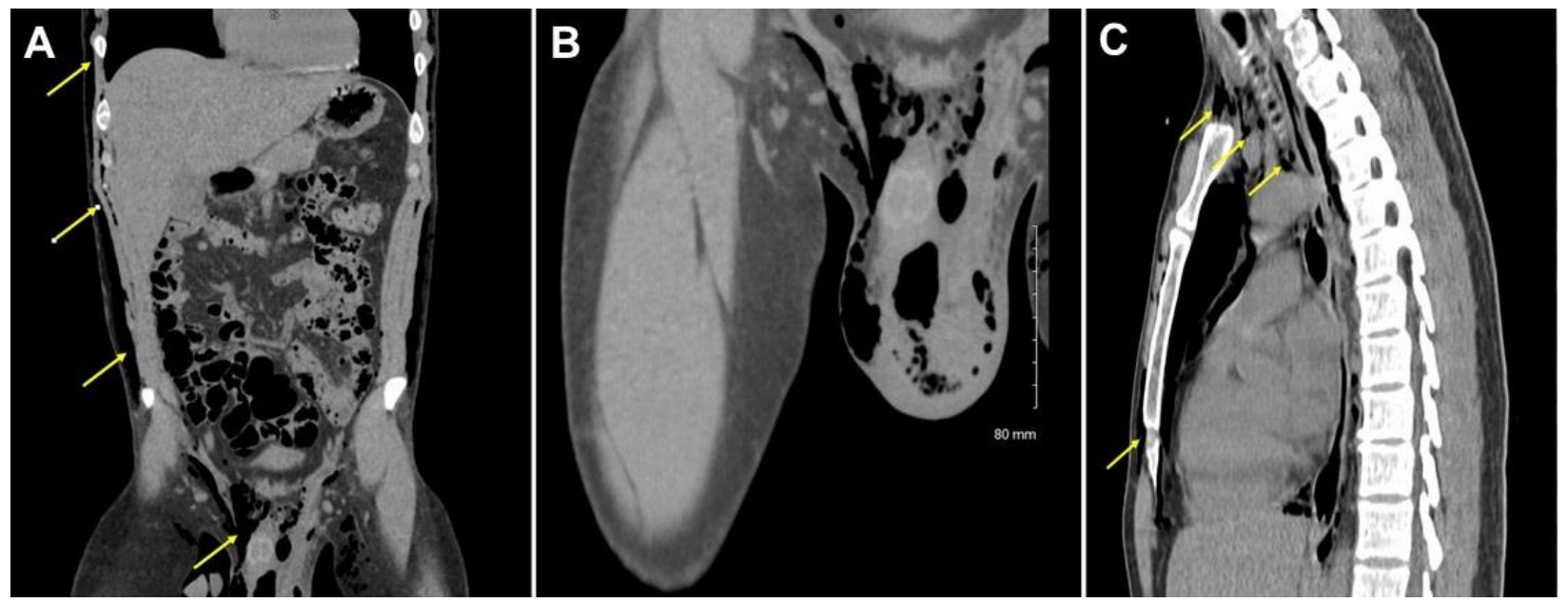

Figure 1. A: Coronal view of abdominal CT scan showing extensive gas formation from the site of trauma (scrotum) ascending along fascial planes, encompassing abdominal wall and chest wall (arrows). B: Close up view of the scrotum and perineum showing tissue necrosis with gas formation. C: Sagittal view of the thoracic CT scan showing gas formation tracking along the chest wall and superior mediastinum (arrows).

\section{Penrose drains}

Figure 2. Status post incision and debridement of scrotum and perineum. 
A 37-year-old man presented with worsening left testicular pain, swelling and redness within 3 days of being poked by a safety-pin during foreplay. Over 24 hours, his left scrotum doubled in size with significant erythema, edema, crepitus and induration. Imaging of scrotum and legs revealed extensive gas formation extending to the retroperitoneum and ascending along fascial planes. Subcutaneous emphysema of abdominal wall, chest wall with mediastinal gas was noted. Investigation showed a shite blood cell count of 22,000 cells $/ \mathrm{mcL}$ with $12 \%$ bands and HIV testing was negative. Intravenous vancomycin and ertapenem were administered on presentation followed by emergent bilateral debridement of the scrotum. Wound/tissue cultures grew methicillin sensitive Staphylococcus aureus, group B Streptococcus and anaerobic Bacteroides. Antibiotics were de-escalated to ciprofloxacin and metronidazole and the patient showed adequate recovery at 30 days of follow up.

Improved survival of Fournier's gangrene can only be achieved by prompt diagnosis and early debridement by an experienced surgical team and microbiology guided use of antibiotics.

Our case brings forward the act of piquerism, a paraphilia which led to rapidly progressive perineal tissue necrosis with bacterial synergism of non-clostridial micro-organisms causing extensive gas formation.

Padmastuti Akella, MD1, Himmat Grewal MD¹, Imola Daniel MD²

${ }^{1}$ Department of Internal Medicine, Saint Vincent Hospital, Worcester, MA

2Division of Infectious Diseases, Saint Vincent Hospital, Worcester, MA

\section{References}

1. Archer CB, Rosenberg WM, Scott GW, MacDonald DM. Progressive bacterial synergistic gangrene in patient with diabetes mellitus. J R Soc Med. 1984;77 Suppl 4:1-3. [PubMed]

2. Yasuda K, Hayashi M, Takeda N, Goshima E, Miura K. A survived case of diabetic nonclostridial gas gangrene and the review of the literatures on microbiological findings. Jpn J Med. 1986 May;25(2):171-4. [CrossRef] [PubMed]

3. Takazawa K, Otsuka H, Nakagawa Y, Inokuchi S. Clinical features of nonclostridial gas gangrene and risk factors for in-hospital mortality. Tokai J Exp Clin Med. 2015 Sep 20;40(3):124-9. [PubMed]

4. Stevens DL, Bryant AE. Necrotizing soft-tissue infections. N Engl J Med. 2017 Dec 7;377(23):2253-65. [CrossRef] [PubMed] 